DE

M E D I C I N A

T R O P I C A L

$\mathrm{DE}$

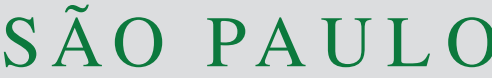

JOURNAL OF THE SÃO PAULO INSTITUTE OF TROPICAL MEDICINE

1 Universidade de São Paulo, Faculdade de Medicina, Hospital das Clínicas, São Paulo, São Paulo, Brazil

${ }^{2}$ Universidade de São Paulo, Instituto de Medicina Tropical de São Paulo, São Paulo, São Paulo, Brazil

Correspondence to: Taniela Marli Bes Universidade de São Paulo, Instituto de Medicina Tropical de São Paulo, Av. Dr. Enéas Carvalho de Aguiar, 470, LIM 49, CEP 05403-000, São Paulo, SP, Brazil Tel: +55 11 3061-7011

E-mail: taniela.bes@usp.br tanielabes@gmail.com

Received: 1 December 2020

Accepted: 14 March 2021

\section{Susceptibility to chlorhexidine and mupirocin among methicillin-resistant Staphylococcus aureus clinical isolates from a teaching hospital}

Taniela Marli Bes ${ }^{\circledR 1,2}$, Lauro Perdigão-Neto ${ }^{1,2}$, Roberta Ruedas Martins², Inneke Heijden², Priscila de Arruda Trindade ${ }^{2}$, Gaspar Camilo², Debora Satie Nagano ${ }^{\circledR 2}$, Diego Mongelos ${ }^{2}$, Ana Paula Marchi², Mariama Tomaz ${ }^{2}$, Larissa Marques de Oliveira ${ }^{2}$, Flavia Rossi ${ }^{1}$, Anna Sara Levin ${ }^{1,2}$, Silvia Figueiredo Costa ${ }^{11,2}$

\section{ABSTRACT}

Despite the widespread use of chlorhexidine (CHX) to prevent infection, data regarding the in vitro action of CHX against methicillin-resistant Staphylococcus aureus (MRSA) are limited. Clinical isolates from Hospital das Clinicas, Sao Paulo, Brazil, identified during 2002/2003 and 2012/2013 were studied to describe the susceptibility to CHX and mupirocin, molecular characteristics, and virulence profile of MRSA. Susceptibility test to Mupirocin was performed by the disk diffusion method and to CHX by the agar dilution technique. PCR for virulence genes, mecA gene and Staphylococcal Cassette Chromosome mec (SCCmec) types were investigated as well. Mupirocin- and CHX-resistant isolates were sequenced using the Illumina $^{\mathrm{TM}}$ plataform. Two hundred and sixteen MRSA clinical isolates were evaluated: 154 from infected and 62 from colonized patients. Resistance to mupirocin was observed in four isolates assigned as SCCmec type III and STs (ST05; ST239 and ST105) carrying mupA and blaZ, two of them co-harboring the ileS gene. Only one isolate assigned as SCCmec type III was resistant to CHX (MIC of $8.0 \mu \mathrm{g} \cdot \mathrm{mL}^{-1}$ ) and harbored the qacA gene. Resistance to chlorhexidine and mupirocin were found in isolates carrying qac $\mathrm{A}$ and mup $\mathrm{A}$ in our hospital. Since these genes are plasmid-mediated, this finding draws attention to the potential spread of resistance to mupirocin in our hospital.

KEYWORDS: MRSA. Chlorhexidine resistance. Mupirocin resistance. Virulence. Molecular profile.

\section{INTRODUCTION}

Methicillin-resistant Staphylococcus aureus (MRSA) is an important cause of severe healthcare-associated infections (HCAI) worldwide and it is associated with high morbidity, mortality and increasing healthcare costs ${ }^{1}$.

It is well known that nasal colonization by $S$. aureus is a risk factor for subsequent S. aureus HCAI, hence many strategies, such as decolonization, have been used to reduce transmission of MRSA. Pre-surgical nasal decolonization with mupirocin (MUP) and extra-nasal with chlorhexidine (CHX) are approaches commonly used and have been associated with a $58 \%$ reduction in post-surgical infections ${ }^{2}$. However, in the last decade, resistance has been reported even during nasal decolonization with mupirocin ${ }^{3}$.

Resistance to mupirocin is mostly codified by three genes (mupA, mupB, 
ileS); тирA gene is typically located on mobile genetic elements, which facilitates the dissemination of this resistance mechanism ${ }^{4} ;$ тирB (isoleucyl-tRNA ligase) catalyzes the attachment of isoleucine to tRNA (Ile) and mupR (ileS) confers a high-level resistance to mupirocin, an Ile-analog that competitively inhibits the activation by Ile-tRNA synthetase, thus inhibiting the protein biosynthesis ${ }^{5}$. Resistance to $\mathrm{CHX}$ is usually mediated by three genes, qacA, that confers export-mediated resistance; $q a c B$, an antiseptic efflux protein, with transmembrane transport function and qacC/smr that is implicated in the resistance to quaternary ammonium compounds and ethidium bromide ${ }^{6}$. The aim of this study was to describe the susceptibility profile to CHX and MUP in MRSA clinical isolates by phenotypic methods and whole genome sequencing, from two different periods with a 10 years gap between them.

\section{MATERIALS AND METHODS}

The present study included isolates from two previous studies conducted at the Hospital das Clinicas of the Faculdade de Medicina of the Universidade de Sao Paulo, a tertiary university hospital with 2,000 beds. One hundred and fifty-four S. aureus isolates from 2002/2003 collected from the dermatology ward patients and sixty-two from 2012/2013 from liver transplant patients, had been previously identified as MRSA. The two previous studies were approved by the Ethics Commission of the Hospital das Clinicas under the approval numbers 1072/04 and $0307 / 09^{7,8}$. We reviewed epidemiological and clinical characteristics, previous use of antimicrobial drugs, year of sample collection and MRSA susceptibility profiles to clindamycin, erythromycin, vancomycin, trimethoprimsulfamethoxazole (TMP/SMX), ciprofloxacin, gentamicin, chloramphenicol and tetracycline. Our hospital does not have a policy to decolonize MRSA with chlorhexidine bath and mupirocin as a routine, these strategies were used only during a MRSA outbreak in neonatal intensive care units.

The Minimum Inhibitory Concentration (MIC) was performed by the broth microdilution method according to the Clinical Laboratory Standards Institute ${ }^{9}$. Multiplex PCR amplifications of $c o \mathrm{~A}$ and mec A genes were performed to confirm the MRSA identification ${ }^{10}$. S. aureus ATCC 29213 and NCTC10442 were used as control samples. The susceptibility to mupirocin and the D-test for clindamycin-inducible resistance were performed by the disk diffusion method; susceptibility to chlorhexidine was investigated by the agar dilution method ${ }^{11}$. Resistance to mupirocin was defined as a zone of $\geq 13 \mathrm{~mm}$ using a $5 \mu \mathrm{g}$ disk $^{12}$. The evaluation of the efflux pump in isolates with the chlorhexidine-susceptible profile was performed using the agar dilution method with and without carbonyl cyanide-m-chlorophenyl hydrazone (CCCP) - Sigma ${ }^{\circledR}$. The product was diluted in $1 \mathrm{~mL}$ of distilled water and added to the Müller Hinton medium at a final concentration of $10 \mathrm{mg} / \mathrm{L}$, whereupon the sample grew from the plaques with only chlorhexidine (4-64 mg/L). The least of 4-fold MIC reduction of the samples will indicate the presence of the efflux pump ${ }^{11}$.

Detection of staphylococcal cassette chromosome mec (SCCmec) types was performed using a multiplex PCR method. MRSA isolate NCTC 10442, N315, 85/2082, JSCS 1968, JCSC1678, MR108, JCSC4469 and WIS (WBG8318), which belong to SCCmec types I, II, III, IVa, $\mathrm{IVb}, \mathrm{IVc}, \mathrm{IVd}$ and $\mathrm{V}$, respectively, were used as positive controls ${ }^{13}$.

Clonality was determined by PFGE (Pulsed-field Gel Electrophoresis) and performed with SmaI FastDigest enzyme (Amersham Pharmacia Biotech, Piscataway, NJ, USA) in the CHEF DRII system (Bio-Rad, Hercules, CA, USA) according to McDougal et al. ${ }^{14}$. The resulting restriction patterns were analyzed by BioNumerics (version 7.1, Applied-Maths, Kortrijk, Belgium). PFGE types and subtypes were defined by groups formed at $80 \%$ Dice similarity cutoffs, on a dendrogram constructed by the unweighted pair group method using average linkages. For comparing band patterns within and between different gels, an optimization of $0.5 \%$ and a position tolerance of $1.5 \%$ were used.

MRSA isolates were selected according to PFGE (one of each PFGE pattern) types to perform the Multilocus Sequence Typing (MLST) as previously described by Enright $e t a l .{ }^{15}$. The sequences of seven housekeeping genes ( $\operatorname{arc} C, \operatorname{aroE}, g l p F, g m k, p t a$, tpi and $y q i L)$ were compared to existing sequences in the MLST database. Sequence types (ST) were assigned according to their allelic profiles ${ }^{15}$. Based on PFGE, virulence genes coding for specific adhesions and toxins in MRSA isolates, $P V L$, lukDE, tst, eta, etb, cfl, fib and fnPA were determined in 62 isolates by multiplex $\mathrm{PCR}^{16}$.

Isolates resistant to mupirocin or/and chlorhexidine (158/2003, 8N/2010, 78I/2011 and P19N/2011) were selected to perform Whole Genome Sequence (WGS) by using the Illumina platform to characterize the resistance and virulence profiles, as well as its evolution over time in our institution. Total DNA was extracted with Illustra bacteria genomicPrep Mini Spin Kit (GE Healthcare Life Sciences, Marlborough, MA, USA). DNA quality was verified using the NanoDrop spectrophotometer (Thermo Scientific, Delaware, USA). The concentration of DNA was checked using the Qubit ${ }^{\circledR}$ fluorometer (Thermo Fisher 
Scientific, Delaware, USA) and the DNA integrity was checked on $1.5 \%$ agarose gels. The whole genome of isolates was sequenced by the MiSeq Illumina ${ }^{\mathrm{TM}}$ (Illumina Inc. San Diego, California, USA). The libraries were prepared with the commercial kit Nextera XT Illumina ${ }^{\mathrm{TM}}$ according to the manufacturer's instructions. The quality of the generated libraries was evaluated in TapeStation System (Agilent Inc., Santa Clara, California, USA). Paired reading segments (paired end reads) with over 500 base pairs were processed in MiSeq Illumina ${ }^{\mathrm{TM}}$ sequencing platform. The quality of the files generated in the sequencing was evaluated by FastQC v.0.11.3 (Babraham Bioinformatics, Cambridge, UK) and Trimmomatic v.0:33 (Usadellab, Aachen, Germany). The genome assembly was performed using the Velvet Optimiser v.2.2.5 (Victorian Bioinformatics Consortium, Clayton, Australia) and the contigs were ordered by Abacas v.1.3.1 (ABAQUS Inc., Providence, USA) using the reference strain Staphylococcus aureus subsp. aureus strain Gv69, whose genome is available on the website of the National Center for Biotechnology Information. The genome was annotated with Prokka v.1:11 (Victorian Bioinformatics Consortium, Clayton, Australia) ${ }^{17-19}$. The ST of the isolates was checked by MLSTfinder tool (PubMLST, Oxford, UK) and confirmed in the database PubMLST ${ }^{20}$. The genes related to resistance тирA, тирB, ileS, blaZ, qacA, $q a c B$ and $q a c C / s m r$ and virulence were searched with Artemis v.16.0.0 (Sanger Institute, Cambridge, UK) by manual curation.

Multiplex PCR for resistance to chlorhexidine genes $q a c A B$ and $q a c C$ and resistance to mupirocin mupA and тир $B$ genes was performed using specific primers and conditions previously described ${ }^{6,11}$ to all isolates with $\mathrm{CHX}$ $\mathrm{MIC} \geq 4 \mathrm{mg} / \mathrm{L}$.

Table 1 - Clinical characteristics of patients colonized or infected by MRSA, in two periods at Hospital das Clinicas, Sao Paulo, Brazil.

\begin{tabular}{|c|c|c|c|c|c|c|}
\hline \multirow{2}{*}{$\begin{array}{l}\text { MRSA Isolates } \\
N: 216\end{array}$} & \multicolumn{3}{|c|}{$\begin{array}{c}\text { 2002/2003 } \\
\text { Total Isolates: } 148\end{array}$} & \multicolumn{3}{|c|}{$\begin{array}{c}\text { 2010/2013 } \\
\text { Total Isolates: } 68\end{array}$} \\
\hline & & $\begin{array}{c}\mathrm{N} \times \operatorname{Mup}_{\mathrm{DD}} \mathrm{R} \\
\mathrm{D}\end{array}$ & $\begin{array}{c}\mathrm{N}^{\circ} \mathrm{CHX} \mathrm{R} \\
\text { Agar dilution }\end{array}$ & & $\begin{array}{l}\mathrm{N}^{\circ} \operatorname{Mup}_{\mathrm{DD}} \mathrm{R} \\
\mathrm{D}\end{array}$ & $\begin{array}{c}\mathrm{N}^{\circ} \mathrm{CHXR} \\
\text { Agar dilution }\end{array}$ \\
\hline $\operatorname{Sex}(M / F)$ & $86 / 62$ & $0 / 1$ & - & $46 / 22$ & $3 / 46$ & $1 / 46$ \\
\hline Age median & $55(0.08-95)$ & 78 & - & $55(33-66)$ & $54(54-60)$ & 64 \\
\hline \multicolumn{7}{|l|}{ Clinical condition } \\
\hline Liver disorder & $9 / 148$ & $0 / 148$ & $0 / 148$ & $68 / 68$ & $3 / 68$ & $1 / 68$ \\
\hline Intensive care units patients & $60 / 148$ & $0 / 148$ & $0 / 148$ & $0 / 68$ & $0 / 68$ & $0 / 68$ \\
\hline Surgical patients & $33 / 148$ & $0 / 148$ & $0 / 148$ & $0 / 68$ & $0 / 68$ & $0 / 68$ \\
\hline Skin disorders & $19 / 148$ & $1 / 148$ & $0 / 148$ & $0 / 68$ & $0 / 68$ & $0 / 68$ \\
\hline Aids patients & $6 / 148$ & $0 / 148$ & $0 / 148$ & $0 / 68$ & $0 / 68$ & $0 / 68$ \\
\hline Hematological and solid cancer patients & $19 / 148$ & $0 / 148$ & $0 / 148$ & $0 / 68$ & $0 / 68$ & $0 / 68$ \\
\hline Other clinical conditions patients & $8 / 148$ & $0 / 148$ & $0 / 148$ & $0 / 148$ & $0 / 148$ & $0 / 148$ \\
\hline
\end{tabular}

MRSA = Methicillin-resistant Staphylococcus aureus; M/F = Male/Female; MUP = Mupirocin; CHX = Chlorhexidine; R = Resistant; DD = Diffusion Disk; Other clinical conditions = Diabetes, hypertension, chronic heart diseases and autoimmune diseases

\section{RESULTS}

The analysis involved 216 isolates: 154 from infected patients and 62 from colonized patients. Among the infection samples, $96 \%$ (149/154) were isolated from blood, being 148 from 2002/2003 and six from 2010/2013. Of the colonization samples, $67 \%$ (42/62) were from the nasal site and 33\% (20/62) were from the inguinal site. The majority was from clinical wards, intensive care units and surgical wards, respectively (Table 1). The four isolates selected for WGS due to resistance to CHX or MUP were identified from patients suffering from cirrhosis caused by Hepatitis C (78I/2011 and P19N/2011), nonalcoholic fatty liver disease (NFLD) (8N/2010), and a patient from the dermatology ward who had erythrodermic psoriasis (158/2003).

Regarding the 216 isolates, susceptibility tests demonstrated that erythromycin, ciprofloxacin and clindamycin showed poor activity against MRSA isolates with more than $81 \%$ of resistance and $58 \%$ (125/216) of the isolates were resistant to TMP/SMX. Comparing the two periods of time, the resistance profiles were similar (Table 2). Considering SCCmec typing, 63\%, 17\%, 13\%, $6 \%$ and $0.4 \%$ were type III, IV, II, I and V, respectively. Among the isolates from 2002/2003, SCCmec, III was the most frequent. Resistance to mupirocin was observed in four isolates $(1,85 \%)$. Twenty-two percent (47/216) of MRSA isolates showed MICs for chlorhexidine $=4.0 \mu \mathrm{g} / \mathrm{mL}$, and only one isolate had MIC of $8.0 \mu \mathrm{g} / \mathrm{mL}$.

The isolates submitted to WGS belong to ST05 (78I; P19N), ST239 (158) and ST105 (8N). These isolates were all SCCmec type III. Regarding the resistance genes, we 
Table 2 - Resistance profile of MRSA isolates, in two periods at Hospital das Clinicas, Sao Paulo, Brazil.

\begin{tabular}{|c|c|c|c|c|c|c|c|c|}
\hline $\begin{array}{l}\text { MRSA Isolates } \\
\mathrm{N}: 216\end{array}$ & \multicolumn{4}{|c|}{$\begin{array}{c}2002 / 2003 \\
N: 148\end{array}$} & \multicolumn{4}{|c|}{$\begin{array}{c}2010 / 2013 \\
N: 68\end{array}$} \\
\hline \multirow{2}{*}{$\begin{array}{l}\text { scCmec type } \\
(\mathrm{I} / \mathrm{II} / \mathrm{III} / \mathrm{IV} / \mathrm{V})\end{array}$} & \multicolumn{4}{|c|}{$0 / 0 / 85 / 63 / 0$} & \multicolumn{4}{|c|}{$2 / 5 / 35 / 26 / 1$} \\
\hline & MIC50 & MIC90 & $\begin{array}{c}\text { R Isolates } \\
(\%)\end{array}$ & $\begin{array}{c}\mathrm{SCC} m e c \mathrm{III} / \mathrm{IV} \\
\mathrm{R}\end{array}$ & MIC50 & MIC90 & $\begin{array}{c}\mathrm{R} \text { Isolates } \\
(\%)\end{array}$ & $\begin{array}{c}\text { SCCmec III/IV } \\
\text { R }\end{array}$ \\
\hline MUP & 25 & 30 & $1 / 148(0.7 \%)$ & $1 / 0$ & 25 & 30 & $2 / 68(3 \%)$ & $2 / 0$ \\
\hline $\mathrm{CHX}$ & 1 & 4 & 0/148 (0\%) & $0 / 0$ & 1 & 4 & 1/68 (1.4\%) & $1 / 0$ \\
\hline VAN & 0,5 & 1 & 0/148 (0\%) & $0 / 0$ & 0,5 & 1 & $0 / 68(0 \%)$ & $0 / 0$ \\
\hline ERI & 256 & 256 & $126 / 148$ (85\%) & $112 / 15$ & 256 & 256 & $61 / 68(90 \%)$ & $14 / 4$ \\
\hline CLI & 256 & 256 & 124/148 (84\%) & $121 / 3$ & 256 & 256 & $54 / 68(80 \%)$ & $0 / 3$ \\
\hline CIP & 16 & 128 & $121 / 148$ (82\%) & $121 / 3$ & 16 & 128 & $56 / 68(82 \%)$ & $12 / 2$ \\
\hline SMTX & 128 & 256 & $112 / 148$ (75\%) & $111 / 1$ & 128 & 256 & $14 / 68(20 \%)$ & $12 / 1$ \\
\hline OXA & 256 & 256 & $148 / 148(100 \%)$ & $111 / 3$ & 256 & 256 & $68 / 68(100 \%)$ & $12 / 2$ \\
\hline
\end{tabular}

MRSA = Methicillin-resistant Staphylococcus aureus; SCCmec = Staphylococcal Cassette Chromosome mec; MIC = minimum inhibitor concentration; R = resistant; $\mathrm{ERI}=$ erythromycin; $\mathrm{CLI}=$ clindamycin; $\mathrm{CIP}=$ ciprofloxacin; $\mathrm{VAN}=$ vancomycin; $\mathrm{OXA}=$ oxacillin; SMTX = sulfamethoxazole-trimethoprim; $\mathrm{CHX}=$ chlorhexidine; MUP = mupirocin

identified mupA and blaZ in all MUP-resistant isolates, two isolates harbored the ileS gene, and mupB was not found. Only one isolate carried qacA and qacC genes, and it was the one that also displayed resistance to $\mathrm{CHX}$ (Table 3).

Overall, we detected 10 different virulence genes or gene clusters among the four isolates (Table 3). Three genes were common to the chlorhexidine- and mupirocin-resistant isolates: $h l g \mathrm{~B}, h l g \mathrm{C}$ and $h l b$. Panton-Valentine Leukocidin
(PVL) was not detected.

The evaluation of resistance to chlorhexidine and the efflux pump inhibitor (CCCP) displayed an important MIC reduction. All the isolates displayed MIC of less than $0.25 \mu \mathrm{g} / \mathrm{mL}$ after the CCCP exposition.

\section{DISCUSSION}

Table 3 - Description of the he main virulence and resistance-associated genes identified by whole genome sequencing.

\begin{tabular}{|c|c|c|c|c|c|c|c|c|c|c|c|c|c|c|c|c|}
\hline $\begin{array}{c}\text { Strain/Year } \\
\text { Unit }\end{array}$ & $\begin{array}{c}\text { MLST/ } \\
\text { SCCmec }\end{array}$ & Plasmids & $\begin{array}{c}\text { MIC CHX } \\
(\mu \mathrm{g} / \mathrm{mL})\end{array}$ & $\begin{array}{c}\mathrm{MIC} \mathrm{CHX} \\
(\mu \mathrm{g} / \mathrm{mL})+ \\
\text { CCCP }\end{array}$ & $\begin{array}{l}\text { DD MUP } \\
(\mathrm{mm})\end{array}$ & $\begin{array}{c}\text { ERI/CLI/CIP/VAN/ } \\
\text { OXA/SMTX } \\
\text { (Resistence genes) }\end{array}$ & mupA & mupB & iles & blaZ & $\operatorname{sep} A$ & $q a c A$ & $q a c B$ & qacC/smr & Exoenzyme & $\begin{array}{c}\text { Other } \\
\text { Virulence } \\
\text { Factors } \\
\end{array}$ \\
\hline $\begin{array}{c}158 / 03 \\
\text { (Dermatology } \\
\text { Ward - } \\
\text { Eritrodermic } \\
\text { psoriasis) }\end{array}$ & ST-239/III & $\begin{array}{l}\text { pLW043 } \\
\text { (qacC) } \\
\text { pKH13 }\end{array}$ & 1.0 & $<0.25$ & 0 & $\begin{array}{l}256 / 256 / 32 / 0.5 / \\
246 / 246 \\
\text { ermA/ermA/-/-/ } \\
\text { mecA/- }\end{array}$ & + & - & + & + & + & - & - & - & $\begin{array}{l}\text { splA, } \\
\text { splB, } \\
\text { aur }\end{array}$ & $\begin{array}{c}\text { hlgA, hlgB, } \\
\text { hlgC, hlb }\end{array}$ \\
\hline $\begin{array}{c}\text { 8N/10 } \\
\text { (Liver } \\
\text { transplant } \\
\text { - Cirrhosis/ } \\
\text { Non-alcoholic } \\
\text { fatty liver } \\
\text { disease) }\end{array}$ & ST-105/III & $\begin{array}{c}\text { pKH7 } \\
\text { pUB110 } \\
\text { pKH21 } \\
\text { pDLK1 } \\
\text { SAP074A }\end{array}$ & 8.0 & $<0.25$ & 20 & $\begin{array}{c}\text { 32/32/64/1/ } \\
64 / 0.25 \\
\text { ermA, ermC, mphC, } \\
m s r A / e r m A, \text { ermC, } \\
m p h C, \text { msrA/norA/-/ } \\
\text { mecA/- }\end{array}$ & - & - & + & + & + & + & - & + & $\begin{array}{l}\text { splA, } \\
\text { splB, } \\
\text { aur }\end{array}$ & $\begin{array}{l}\text { ser, sej, } \\
\text { sed, hlb, } \\
\text { lukD, lukE, } \\
\text { hlgA, hlgB, } \\
\text { hlgC }\end{array}$ \\
\hline $\begin{array}{c}78 \mathrm{l} / 11 \\
\text { (Liver } \\
\text { transplant } \\
\text { - Cirrhosis/ } \\
\text { Hepatitis C } \\
\text { virus) } \\
\end{array}$ & ST-5/III & $\begin{array}{c}\text { pLW043 } \\
\text { (qacC) } \\
\text { SAP101A } \\
\text { (blaZ) } \\
\text { pTW20 } \\
\text { (qacA/B) }\end{array}$ & 2.0 & $<0.25$ & 0 & $\begin{array}{c}32 / 32 / 32 / 1 / \\
64 / 0.25 \\
\text { ermA/ermA/norA/-/ } \\
\text { mecA/- }\end{array}$ & + & - & - & + & + & - & - & + & $\begin{array}{l}\text { splA, } \\
\text { splB, } \\
\text { aur }\end{array}$ & $\begin{array}{l}\text { sem, seo, } \\
\text { hlb, lukD, } \\
\text { lukE, hlgA, } \\
\text { hlgB, hlgC }\end{array}$ \\
\hline $\begin{array}{c}\text { P19N/11 } \\
\text { (Liver } \\
\text { transplant } \\
\text { - Cirrhosis/ } \\
\text { Hepatitis C } \\
\text { virus) }\end{array}$ & ST-5/III & $\begin{array}{c}\text { pLW043 } \\
\text { (qacC) } \\
\text { SAP101A } \\
\text { (blaZ) } \\
\text { pTW20 } \\
\text { (qacA/B) }\end{array}$ & 2,0 & $<0,25$ & 0 & $\begin{array}{c}32 / 32 / 32 / 1 / \\
64 / 0,25 \\
\text { ermA/ermA/norA/-/ } \\
\text { mecA/- }\end{array}$ & + & - & + & + & + & - & - & + & $\begin{array}{l}\text { splA, } \\
\text { splB, } \\
\text { splE, } \\
\text { aur }\end{array}$ & $\begin{array}{l}\text { hlb, lukD, } \\
\text { lukE, hlgB, } \\
\text { hlgC }\end{array}$ \\
\hline
\end{tabular}


This study identified the mupA gene in mupirocinresistant MRSA isolates and the $q a c \mathrm{~A} / \mathrm{C}$ gene from a CHX-resistant isolate obtained from a liver transplant patient and from dermatological ward inpatients that had never used mupirocin before. These genes are potentially plasmid-mediated and can disseminate quickly with the increased use of CHX and MUP. Although CHX baths and nasal decolonization with mupirocin have been shown to decrease the risk of infection in patients from intensive care units and surgical wards, these strategies, despite universally implemented, should be used cautiously as they may favor a selective pressure ${ }^{21}$.

Although the low rate of MUP- and CHX-resistant isolates found in our hospital, we observed that the resistance to MUP raised from $0.67 \%$ (1/148) to $4.4 \%$ (3/68) in 10 years, in our MRSA isolates. These rates are still low in comparison with the study by Munoz-Gallego et al. ${ }^{22}$, who described a resistance to MUP around 15\% in blood and nasal isolates, in samples collected between 2012/2014, in Madrid, Spain. In contrast, Brazilian data ${ }^{23}$ reported low rates $(1.1 \%)$ of MUP-resistant MRSA, in children with atopic dermatitis in Porto Alegre, Brazil, similar to our findings, and a higher rate described by Moura et al. ${ }^{24}$ who presented a MUP-resistant MRSA rate of $72 \%$ in samples from nurses' saliva.

Our four MUP-resistant samples are resistant to ciprofloxacin and clindamycin as well. Previous reports have also demonstrated an association between resistance to CHX genes and other antimicrobial resistances in staphylococci, by the efflux pump mechanism ${ }^{25}$. The resistance to gentamicin, tetracycline and macrolides may be located alongside the тирA gene, on the same plasmid; the treatment with mupirocin may offer a selective pressure for antibiotics frequently used for the treatment of $S$. aureus infections. A high-level of resistance has been associated with resistance to ciprofloxacin, erythromycin and clindamycin as well ${ }^{26}$, and in three of our four isolates we found resistance to these antibiotics.

Both, high and low level resistance to mupirocin, reduce the effectiveness of decolonizing strategies for $S$. aureus or MRSA. The increased use of mupirocin for treatment of wounds and pressure sores are strongly associated with this resistance ${ }^{1}$. A possible association between the presence of $q a c$ genes and resistance to MUP has been suggested by Fritz et al.,$^{27}$. Lee et al. ${ }^{28}$, in a case-control study of MRSA decolonization, demonstrated that even low levels of resistance to MUP combined with genotypic resistance to CHX significantly increased the risk of decolonization failure and persistent carriage of MRSA. Regarding our isolates, the $q a c \mathrm{C}$ gene was found in $2 / 3$ of the MUP-resistant isolates.
Some studies have reported a reduced susceptibility to $\mathrm{CHX}$ in isolates carrying $q a c A / B$ genes and in isolates carrying $q a c C$ genes, as well. A recent report demonstrated that although MICs from $q a c$-positive and qac-negative isolates were identical, $q a c$-positive isolates could survive after exposure to $2 \% \mathrm{CHX}$ for up to $5 \mathrm{~min}$, but qac-negative isolates could $\operatorname{not}^{29}$. A possible explanation was that exposure to low concentrations of CHX over an extended period of time may overwhelm the efflux ability of the qac pumps to protect the bacterium ${ }^{27}$.

The WGS identified virulence genes as $l u k D$ and lukE, in three isolates, and they are part of a bicomponent leucotoxin that acts by forming pores in target cells membranes. They have hemolytic and leucotoxic activities and they are as effective as PVL for inducing dermonecrosis in animal model ${ }^{30}$. However, Panton-Valentine Leukocidin (PVL) was not detected. Additionally, we found toxin-producing genes responsible for hemolytic and leucotoxic activities $(h \lg A, h \lg B$ and $h \lg C$ ), the intoxication staphylococcal food poisoning syndrome (seJ, seO and $\mathrm{seD}$ ), a gene responsible for catalyzing the attachment of serine to tRNA (ser) and an exotoxin that attacks blood cell membranes, causing cell rupture $(h l b)$.This study investigated the enterotoxin gene cluster coding for the exoenzymes $s p l A, s p l B$, aur and $s p l E$, and the first three were found in the four sequenced samples.

Our study presented limitations as it is a retrospective study, we did not evaluate the expression of virulence factors and we could not determine the MICs to mupirocin, since the test is not available in the country. Nevertheless, the monitoring of resistance to mupirocin and chlorhexidine in clinical MRSA isolates is important to recognize the local resistance profile.

\section{CONCLUSION}

In summary, $\mathrm{CHX}$ and mupirocin-resistant MRSA isolates harboring potential plasmid-mediated resistance genes, such as $q a c \mathrm{~A}, q a c \mathrm{C}, \operatorname{mup} \mathrm{A}$ and iles were isolated from patients that had never used mupirocin, even considering the transmission among health care professionals and cross transmissions. These findings highlighted the potential dissemination of the resistance to CHX and MUP in our hospital.

\section{CONFLICT OF INTERESTS}

The authors certify that they have no affiliations with or involvement in any organization or entity with any financial interest in the subject matter or materials discussed in this manuscript. 


\section{FUNDING}

This work was supported by the Medical Investigation Laboratory (LIM-49), University of Sao Paulo.

\section{REFERENCES}

1. Hetem DJ, Bonten MJ. Clinical relevance of mupirocin resistance in Staphylococcus aureus. J Hosp Infect. 2013;85:249-56.

2. Bode LG, Kluytmans JA, Wertheim HF, Bogaers D, Vandenbroucke-Grauls CM, Roosendaal R, et al. Preventing surgical-site infections in nasal carriers of Staphylococcus aureus. N Engl J Med. 2010;362:9-17.

3. McNeil JC, Hulten KG, Kaplan SL, Mason EO. Mupirocin resistance in Staphylococcus aureus causing recurrent skin and soft tissue infections in children. Antimicrob Agents Chemother. 2011;55:2431-3.

4. Barakat GI, Nabil YM. Correlation of mupirocin resistance with biofilm production in methicillin-resistant Staphylococcus aureus from surgical site infections in a tertiary centre, Egypt. J Glob Antimicrob Resist. 2016;4:16-20.

5. Seah C, Alexander DC, Louie L, Simor A, Low DE, Longtin J, et al. MupB, a new high-level mupirocin resistance mechanism in Staphylococcus aureus. Antimicrob Agents Chemother. 2012;56:1916-20.

6. Bjorland J, Sunde M, Waage S. Plasmid-borne smr gene causes resistance to quaternary ammonium compounds in bovine Staphylococcus aureus. J Clin Microbiol. 2001;39:39994004.

7. van der Heijden IM, Marques de Oliveira L, Brito GC, Abdala E, Freire MP, Rossi F, et al. Virulence and resistance profiles of MRSA isolates in pre-and post-liver transplantation patients using microarray. J Med Microbiol. 2016;65:1060-73.

8. Pacheco RL, Lobo RD, Oliveira MS, Farina EF, Santos CR, Costa SF, et al. Methicillin-resistant staphylococcus aureus (MRSA) carriage in a dermatology unit. Clinics (Sao Paulo). 2011;66:2071-7.

9. Clinical and Laboratory Standards Institute. M100 performance standards for antimicrobial susceptibility testing. $30^{\text {rd }} \mathrm{ed}$. Wayne: CLSI; 2020.

10. Kearns AM, Seiders PR, Wheeler J, Freeman R, Steward M. Rapid detection of methicillin-resistant staphylococci by multiplex PCR. J Hosp Infect. 1999;43:33-7.

11. Abuzaid A, Hamouda A, Amyes SG. Klebsiella pneumoniae susceptibility to biocides and its association with cepA, qac $\Delta \mathrm{E}$ and qacE efflux pump genes and antibiotic resistance. J Hosp Infect. 2012;81:87-91.

12. Malaviolle X, Nonhoff C, Denis O, Rottiers S, Struelens MJ. Evaluation of disc diffusion methods and Vitek 2 automated system for testing susceptibility to mupirocin in Staphylococcus aureus. J Antimicrob Chemother. 2008;62:1018-23.

13. Zhang K, McClure JA, Elsayed S, Louie T, Conly JM. Novel multiplex PCR assay for characterization and concomitant subtyping of staphylococcal cassette chromosome mec types I to V in methicillin-resistant Staphylococcus aureus. J Clin Microbiol. 2005;43:5026-33.

14. McDougal LK, Steward CD, Killgore GE, Chaitram JM, McAllister SK, Tenover FC. Pulsed-field gel electrophoresis typing of oxacillin-resistant Staphylococcus aureus isolates from the United States: establishing a national database. J Clin Microbiol. 2003;41:5113-20.

15. Enright MC, Day NP, Davies CE, Peacock SJ, Spratt BG. Multilocus sequence typing for characterization of methicillinresistant and methicillin-susceptible clones of Staphylococcus aureus. J Clin Microbiol. 2000;38:1008-15.

16. Baba-Moussa L, Anani L, Scheftel JM, Couturier M, Riegel P, Haïkou N, et al. Virulence factors produced by strains of Staphylococcus aureus isolated from urinary tract infections. J Hosp Infect. 2008;68:32-8.

17. Galens K, Orvis J, Daugherty S, Creasy HH, Angiuoli S, White $\mathrm{O}$, et al. The IGS standard operating procedure for automated prokaryotic annotation. Stand Genomic Sci. 2011;4:244-51.

18. Zerbino DR. Using the Velvet de novo assembler for shortread sequencing technologies. Curr Protoc Bioinformatics. 2010;11:11.5.

19. Zerbino DR, Birney E. Velvet: algorithms for de novo short read assembly using de Bruijn graphs. Genome Res. 2008;18:821-9.

20. Larsen MV, Cosentino S, Rasmussen S, Friis C, Hasman H, Marvig RL, et al. Multilocus sequence typing of total-genomesequenced bacteria. J Clin Microbiol. 2012;50:1355-61.

21. Loveday HP, Wilson JA, Pratt RJ, Golsorkhi M, Tingle A, Bak A, et al. epic3: national evidence-based guidelines for preventing healthcare-associated infections in NHS hospitals in England. J Hosp Infect. 2014;86 Suppl 1:S1-70.

22. Muñoz-Gallego I, Infiesta L, Viedma E, Perez-Montarelo D, Chaves F. Chlorhexidine and mupirocin susceptibilities in methicillin-resistant Staphylococcus aureus isolates from bacteraemia and nasal colonisation. J Glob Antimicrob Resist. 2016;4:65-9.

23. Bessa GR, Quinto VP, Machado DC, Lipnharski C, Weber MB, Bonamigo RR, et al. Staphylococcus aureus resistance to topical antimicrobials in atopic dermatitis. An Bras Dermatol. 2016;91:604-10.

24. Moura JP, Gir E, Rosa JO, Belíssimo-Rodrigues F, Cruz ED, Oliveira AC, et al. Resistência à mupirocina entre isolados de Staphylococcus aureus de profissionais de enfermagem. Acta Paul Enferm. 2010;23:399-403.

25. Costa SS, Viveiros M, Amaral L, Couto I. Multidrug efflux pumps in Staphylococcus aureus: an update. Open Microbiol J. 2013;7:59-71.

26. Diep BA, Gill SR, Chang RF, Phan TH, Chen JH, Davidson MG, et 
al. Complete genome sequence of USA300, an epidemic clone of community-acquired meticillin-resistant Staphylococcus aureus. Lancet. 2006;367:731-9.

27. Fritz SA, Hogan PG, Camins BC, Ainsworth AJ, Patrick C, Martin MS, et al. Mupirocin and chlorhexidine resistance in Staphylococcus aureus in patients with community-onset skin and soft tissue infections. Antimicrob Agents Chemother. 2013;57:559-68.

28. Lee AS, Macedo-Vinas M, François P, Renzi G, Schrenzel J, Vernaz N, et al. Impact of combined low-level mupirocin and genotypic chlorhexidine resistance on persistent methicillinresistant Staphylococcus aureus carriage after decolonization therapy: a case-control study. Clin Infect Dis.
2011;52:1422-30.

29. Mc Gann P, Milillo M, Kwak YI, Quintero R, Waterman PE, Lesho E. Rapid and simultaneous detection of the chlorhexidine and mupirocin resistance genes $\mathrm{qac} \mathrm{A} / \mathrm{B}$ and mupA in clinical isolates of methicillin-resistant Staphylococcus aureus. Diagn Microbiol Infect Dis. 2013;77:270-2.

30. Gravet A, Couppié P, Meunier O, Clyti E, Moreau B, Pradinaud $\mathrm{R}$, et al. Staphylococcus aureus isolated in cases of impetigo produces both epidermolysin A or B and LukE-LukD in $78 \%$ of 131 retrospective and prospective cases. J Clin Microbiol. 2001;39:4349-56 